\title{
Problems of Sustainable Energy in sub-Saharan Africa and Possible Solutions
}

\author{
Fortune Ganda \\ Turfloop Graduate School of Leadership, \\ Faculty of Management and Law, University of Limpopo, South Africa \\ fochi555@yahoo.com \\ Collins C Ngwakwe \\ Turfloop Graduate School of Leadership \\ Faculty of Management and Law, University of Limpopo, South Africa. \\ collins.ngwakwe@ul.ac.za
}

\section{Doi:10.5901/mjss.2014.v5n6p453}

\begin{abstract}
This paper examines the problems of promoting sustainable energy in sub-Saharan Africa (SSA) and suggests possible solutions. Using current literature, the major problems identified are: continued employment of fossil fuel subsidies; presence of monopoly structures in the energy sectors; regulatory and macroeconomic risks in sustainable energy schemes; large capital required to fund sustainable schemes; high transaction costs; low carbon risk and negative social impacts. The solutions identified are that countries must employ renewable energy targets; deploy feed-in tariffs; integrate Clean Development Mechanisms (CDMs); phase out monopoly power utilities; seek external assistance; introduce tax incentives; increase independent power producers and expand Rural Electrification Programmes.
\end{abstract}

Keywords: Development Finance; Sub-Saharan Africa (SSA); Sustainable Energy.

\section{Introduction}

In recent years sub-Saharan Africa (SSA) has been experiencing strong economic development (WorldBank, 2005) but energy demand has also risen (UNECA/UNEP, 2007). Thus, given low industrialisation capacity in SSA (ICSU, 2007), development finance has become important towards promoting sustainable energy so that SSA is able to reduce energy poverty and ensure that the region has a green (low-carbon) and clean energy network (AfDB, 2008), which will inevitably improve the people's standards of living, create employment opportunities and support growth of small and medium enterprises (Karekezi et al., 2002; WEC, 2005). The current challenges facing SSA include lack of access to energy. For instance, electricity access in 47 countries that are in sub-Saharan Africa (SSA), with the exception of South Africa, equals generation capacity of Argentina alone (US EIA, 2011). Furthermore, a quarter of its generation capacity lacks adequate maintenance and has outdated equipment (US EIA, 2011). Evidently, the cost of generating electricity in SSA adds up to a high US\$0.18/kWh when compared to South Asia-US\$0.04/kWh and East Asia-US\$0.07/kWh (AfDB, 2010). So, SSA possess only $24 \%$ share towards electricity access which is the lowest globally (Eberhard et al., 2008). Moreover, only $8 \%$ of rural households have access to electricity and $85 \%$ of the people depend on biomass energy (OECD/IEA 2010; Ram, 2006; ICSU, 2007). Briefly, just 2 to 5\% of rural households in SSA are linked to a large energy grid, when compared to a high 98\% for Thailand (Martinot et al., 2002). It has also been reported that distribution losses of electricity in SSA added up to $20 \%$ of total energy use on an annual basis between 2000 and 2008 when they were contrasted to only $8 \%$ for Europe and North America (US EIA, 2011). Therefore, Africa's energy sector has poor electricity reliability shown by 56 days of electricity outage annually (UNEP, 2013). For example, Senegal records 25 days, Burundi reports 144 days and Tanzania accounts for 63 days of power outages (AfDB, 2010). Power outages have also caused losses in SSA production industries estimated to be as high as $20 \%$ (UNEP, 2013). Thus for firms, the expenses incurred by back-up generators that supply power cost seven times higher than power from the national grid (Foster and Steinbuks, 2008), causing 6\% and 16\% losses in revenue and damaged stock respectively (Foster and Steinbuks, 2008). In the same vein, public health risks have also been identified in mining and production industries through burning fossil fuels as well as inhalation of black-carbon smoke from cook-stoves, causing up to 1.9 million deaths in Africa's (UN-Energy/Africa, 2011; UNEP FI, 2012). Literature also records that 393000 deaths in SSA for the 
year 2002 were a result of inhaling polluted air from burning biomass sources of energy (ICSU, 2007). For these reasons, most countries in SSA still do not have local sources of finance that support energy resource development (ICSU, 2007). All things considered, this paper examines the problems of sustainable energy in sub-Saharan Africa and possible solutions.

The main questions posed by this study are: What are the problems of sustainable energy provision in SSA? What are the possible solutions to the problems of promoting sustainable energy in SSA? Therefore, the associated objectives of this study are: to analyse the problems of sustainable energy provision in SSA and to determine the possible solutions to the problems of promoting sustainable energy in SSA.

The structure of the paper is as follows: section 2 outlines an overview of sustainable energy in SSA; section 3 evaluates problems of sustainable energy in SSA; section 4 examines the solutions towards supporting sustainable energy in SSA, and section 5 presents the conclusion.

\section{Overview of Sustainable Energy in SSA}

Davidson (2002) defines sustainable energy "as energy providing affordable, accessible and reliable energy services that meet economic, social and environmental needs within the overall developmental context of the society for which the services are intended, while recognizing equitable distribution in meeting those needs." Thus, sustainable energy refers to renewable energy sources (hydro, wind, wave, biofuel, geothermal, solar, tidal and biomass power) and technologies that enhance energy efficiency (UNEP, 2008; 2010; UNEP FI, 2012; ICSU, 2007; IPCC, 2011). In SSA, Millennium Development Goals (MDGs) attainment will be made possible once renewable energy adoption and investments have taken place (ODI, 2012). On that account, alleviating energy poverty is of prime importance since energy provision affects most activities that humans undertake (UN-Energy/Africa, 2011). For this reason, renewable energy sources have a large role to play in Africa if disadvantaged communities are to access energy (Karekezi et al., 2002). Thus, in Tanzania, Zara Solar company in collaboration with Savings and Credit Cooperative societies (SACCOs) developed solar project schemes which provided cheap and clean solar power to the rural area of Mwanza region, in addition to affordable loan repayment schemes which enhance all poor households to acquire solar home equipment (IFC, 2012) since this group has been excluded from the conventional mainstream banking sector. To date, over 60000 rural households have benefited from the project, plus, they also receive solar power maintenance support (IFC, 2012).

Hydroelectricity is the main energy source in SSA (ICSU, 2007; UNEP, 2008), but it has caused social conflict (if practised on a larger scale), environmental degradation and it has also been affected by drought. That being the case, other renewable energy sources need to be integrated in many SSA countries. For instance, rural areas in SSA (where $66 \%$ of the population lives) could be supplied with renewable energy systems that are decentralised and deployed in a modular structure, thereby providing the most appropriate energy source for both small and off-grids by reducing high costs (AfDB,2010). Thus, REN21 (2010) explains that off-grid renewable energy frameworks are sustainable and are less expensive; hence rural areas in developing countries can significantly benefit from its network. Consequently, small and off-grid energy (for instance, roof top solar and heater systems) are significantly cheaper than large scale built energy networks (AfDB, 2008; Martinot et al., 2002). Thiam (2010) demonstrates that research done in three rural regions of Senegal shows that electricity generated from PV appliances produces lesser costs than electricity that comes by expanding grid networks.

In another study, GEF (2009) reports that it contributed US\$75 million through WorldBank/IDA and the Uganda government added US\$9 million towards the Ugandan Energy for Rural Transformation Project II. Thus, PV installations were to be installed in households and institutions, plus rural households were to be supplied with independent energy grids. Overall, the project was also expected to reduce 50 tonnes and 248 tonnes of carbon emissions in year 2 and year 4 respectively. In line with this view, IPCC (2011) comments that renewable energy consumption generates considerably minimised greenhouse gas emissions when compared to fossil fuels. For example, significant contributions from IBRD, CTFm, AfDB and Agense Francaise de Development amounting to US $\$ 350$ million was put forward to support the Sere 100MW wind farm project in South Africa as from October 2013 (KPMG,2011). The Sere project is important towards promoting cleaner production through carbon emissions reduction, preserving scarce water resources as it consumes little water, along with supplying the country with $100 \mathrm{MW}$ of electricity (ESKOM, 2013). In a related study, the WorldBank, DEG, AfDB and other partners contributed a total of US\$250 million towards the Bujagali 250MW hydro power plant in Uganda (KPMG, 2011). The project would reduce power shortages, supply Uganda's energy produced from renewables to $90 \%$, and it is also estimated that 900000 Certified Emissions Reductions (CERs) annually will be attained (Alstorm, 2013).

Research proves that Africa possesses up to $11 \%$ of hydropower energy that have not been exploited and only $3 \%$ 
has presently been put to use (World Energy Council, 2010). Therefore, Kariba North Expansion Project (KNBEP) in Zambia is one hydro-power project designed to extend provision of hydro-electricity and it received financial assistance which included US\$315 million from Chinese Bank and US\$115 million from DBSA (TMSA, 2010; KPMG, 2011). The project was expected to produce an extra $720 \mathrm{MW}$ of electricity, thereby reducing power shortages and minimising costs of importing electricity during peak hours (TMSA, 2010). Indeed, there is growing demand for energy but fossil fuels are also subject to depletion, making them very expensive as a result. For example, global energy needs have been estimated to grow more than forty percent of the current levels by the year 2030 (OPEC, 2010), and 50\% of that share will be fossil fuels (OECD/IEA, 2010).

Existing technology can exploit the vast renewable energy potential that is found in most of the SSA's countries (Deichmann et al., 2010). For example, daily solar radiation ranges from $4 \mathrm{kWh} / \mathrm{m}^{2}$ to $6 \mathrm{kWh} / \mathrm{m}^{2}$ in many regions of SSA (REEEP/UNIDO, 2011), and up to 9000MW of geothermal electricity can be generated in the Great Rift Valley (Holm et al., 2010; REEEP/UNIDO, 2011) and wind energy can be generated in SSA's coastal areas and eastern highlands of countries such as Chad, Kenya, Mauritania, Cape Verde and Sudan, with generation potential of 10600 TWh per year (ICSU, 2007). Besides, Biomass electricity through using 30\% of agricultural remains and $10 \%$ of wood residues from wood processing plants in SSA has potential to generate an additional 1500MW of power supply (Dasappa, 2011). Therefore, as documented in the Kyoto Protocol (Clean Development Mechanisms), SSA's renewable energy structures can be legally certified to acquire carbon credits on global carbon markets (World Bank, 2008; Timilsina et al., 2010). For instance, in year 2008, Uganda installed 550MW of renewable energy and 315MW of this total was hydro-based, and in 2010 an additional 300MW of renewable energy was also installed for Clean Development Mechanisms initiatives (UNEP, 2012).

Despite all these developments undertaken in an effort to foster economic development and meet rising energy demand, Africa's energy sector needs to acquire extra energy and sufficient funding needs to be mobilised annually. AfDB (2010) suggests that adequate finance is important to maintain and operate current power facilities and extra funding is crucial to support long-term investments in the sector. Hence, AfDB determined funds amounting to US\$547 billion in investment required to support clean energy provision in SSA countries (AfDB, 2008). Consequently, private entities have improved their engagement in sustainable energy activities in SSA by assuming crucial roles as debt and equity financiers, consultancy and establishing public-private partnerships (PPPs) (UNEP FI, 2012).

Examples of PPPs include The Enlighten-Initiative, which is a project undertaken by UNEP, AusAid, OSRAM and Phillips among other allies working with African governments with the aim of providing energy efficient lighting. The project is currently operating in 23 African countries in order to do away with inefficient incandescent lamps by year ending 2016 (UNEP, 2013). For this reason, if carbon emissions of up to 13 metric tonnes can be reduced, electricity will be available to 14.5 million households and 20.5tWh electricity can be saved in Africa alone (UNEP FI, 2012). In a separate study, CEPEX-Rwanda (2010) reports that IDA contributed US\$25 million, NDF added US\$9 million, ELECTROGAZ contributed US\$150 000 and the government of Rwanda offered US $\$ 14.56$ million towards alleviating power outages and rebuilding the country's energy sector, which has witnessed complete construction of Kibogora, Karongi and Birembo power substations. Such practices support Briceño-Garmendia et al. (2008) who note that better energy systems in SSA countries' power sectors could increase these countries revenues estimated to be $0.8 \%$ of Africa's gross domestic product.

However, if investment and finance cannot be increased in SSA power sectors, then half of the region's population will not have electricity by 2030 , and the rural population who use traditional energy sources will be the highest worldwide (UN-Energy/Africa, 2011). On that note, given the rate of electricity connections that have taken place in the last 10 years, providing electricity to the whole of Africa can be estimated to take more than 80 years (IEA, 2002). BriceñoGarmendia et al. (2008) suggest that SSA countries' total energy investments for new energy systems and maintenance, which adds up to US $\$ 43$ billion yearly from 2006 to 2015, must be supported. Accordingly, SSA countries have continued to form important partnerships with interested developmental institutions so as to improve sustainable energy access. For instance, the Ministry of Energy-Mozambique (2009) reports that the World Bank offered US\$110 million and OPEC Fund for International Development (OFID) added US\$8 million towards developing energy projects under the name Energy Development and Access Project (EDAP APL-2). These projects will promote adoption of renewable energy sources, support rural electrification capacity and enhance capacity building of the country's energy sector where only $10.5 \%$ households have access to electricity.

Moreover, increase in government's reluctance has grown so as to reduce their dependence on Middle East countries which, at present, most of them are facing serious political crises (ODI, 2012). Furthermore, renewable energy sources are well distributed worldwide than fossil fuel resources that are usually centralised on a single area. Hence, the vast geographical distribution of renewable energy guarantees energy markets and potential investors that they will be 
less affected by policy changes and political turmoils (REN21, 2011). This has led to growth of developmental schemes that include OLKARIA III in Kenya, which provides geothermal electricity to Kenya's people, along with its business enterprises. At its start, the OLKARIA III geothermal project was unable to expand owing to financial problems. On that account, German Investment Corporation contributed $€ 30$ million, European Development Finance Institutions added €25 million, and smaller contributions also came from other developmental partners. The finalised total amount was announced to be US\$119.7 million (DEG, 2010; PIDG, 2013). As such, government tax was expected to be $€ 5$ million, upfront fees US\$3million, royalty charges US\$5 million annually, plus a $6.5 \%$ return on equity was anticipated (DEG, 2010; PIDG, 2013). In that way, these interventions improve industry and business performance, add vital revenue to the country, reduce energy poverty and foster overall economic advancement of the nation.

\section{Problems of Sustainable Energy Provision}

This section identifies sustainable energy problems in SSA: continued employment of fossil fuel subsidies; the presence of monopoly structures in the energy sectors; regulatory and macroeconomic risks in sustainable energy schemes; large capital required to fund sustainable schemes; high transaction costs; low carbon risk and negative social impacts. These are discussed in the following sections.

\subsection{Continued employment of fossil fuel subsidies}

Fossil fuel subsidy refers to government practices which minimise costs of fossil fuel energy generation, increase the price collected by power producers and minimise the price which consumers pay. Beck and Martinot (2004) suggest that fossil fuel subsidies exist in the form of research and development expenditure, leases, waste removal, tax incentives, liability insurance and specific budget transfers. Thus, through minimising the price of energy produced from fossil fuel energy sources, subsidies fossil fuels are more economically viable when compared to renewable fuels. Therefore, fossil fuel energy sources have continued to receive subsidies which make renewable energy generation very expensive in the short term and thus hard to implement on a larger scale. For example, in 2009 , fossil fuel subsidies were US\$312 billion, whilst US $\$ 57$ billion was for renewable energy sources (IEA, 2011). In addition, renewable energy has been subsidised at US5c/kWh compared to just US0.8c/kWh for non-renewables, which inevitably increase greenhouse emissions (IEA, 2010). Hence, removing fossil fuel subsidies could lead to 10\% minimisation in carbon emissions by 2050 (OECD, 2010). In addition, fossil fuel subsidies benefit high-income populations because of associated high consumption levels than the poor in developing countries (of the bottom $40 \%$ in income composition, only $15-20 \%$ received fossil fuel subsidies) (IEA,2010). Interestingly, renewable energy adoption is expected to cost US\$36 billion by year 2030 , yet this value is $8 \%$ less when compared to 2009 global subsidies for non-renewable energy (OECD/IEA, 2010).

\subsection{The presence of monopoly structures in the energy sectors}

The energy sector in SSA is dominated by a responsible government parastatal that is usually a monopoly, highly inflexible and hardly gives the private sector access to energy markets (Nkwetta et al. 2010; UNEP FI, 2012). Such a scenario is highly politically influenced so as to reduce and keep energy prices very low, which affects the financial status of the country's energy sector, thereby creating unfavourable environments for private financiers' engagement. Thus, African countries' monopoly power sectors that are not reformed reduce competition by not introducing a number of rivals in the sector. Also, cost-effective tariff system without subsidies is hard to achieve, and it doesn't establish sound and amended electricity laws (UNIDO, 2012). Moreover, monopolism in the power sector has been characterised by insufficient supplies, expensive customer charges, and high power outages (Rambo, 2013) which are highly common in South Africa, Côte d'Ivoire and Mauritius (Pegels, 2009; Rambo, 2013)

\subsection{Regulatory and macroeconomic risks in sustainable energy schemes}

The regulatory and macroeconomic risks in SSA have a tendency to be so noticeable that private investors financial returns are openly low, hence suitable and financeable energy schemes are difficult to implement (UNEP FI, 2012). For instance, public incentive mechanisms instituted by the government to enable private investors to fund sustainable energy practices will make them risk averse since they do not guarantee that they will be implemented for a long time, and the legal system may not remain the same. Moreover, energy technologies being used may not perform at all or they may perform below the expected levels; highly common in SSA (UNEP FI, 2012). Thus, some renewable energy 
schemes have failed to start as the countries that require funds show a large risk base (UN-Energy/Africa, 2011). For example, only Morocco, Tunisia, South Africa and Botswana have qualified to be in the investment grade rankings, whilst the remaining 49 African states were categorised to be in the non-investment group (Jaramillo, 2010). Thus, nations that have not been added in the investment grade classification are characterised by poor market data, characterised with young, inexperienced and illiquid capital markets (Knights, 1998) and are not able to issue debt on international markets. Moreover, private investors shun these countries since they do not have independent credit systems; hence, borrowing expense is considerably high. Furthermore, political conflicts and tensions within countries (e.g. Mali, Côte d'Ivoire, Somalia) have also contributed to renewable energy projects being disrupted, destroyed and reversed (AfDB,2010).

\subsection{Large capital required to fund sustainable schemes}

Renewable energy technologies in SSA will require an initial large capital base when compared with expenditure on already integrated technologies in operation as in more developed economies (Pegels, 2009). Therefore, there is a high investment risk for SSA since few investors prefer initial capital investment in renewable technologies than for operations expenditure (UNEP FI, 2012). Thus, the levelised costs of energy involved with integrating renewable energy systems generated are high when they are compared to conventional energy models (IPCC, 2011). Briefly, Fraunhofer (2012) demonstrates that levelised cost of electricity for renewables depends on particular purchase investments for renewable technologies, local conditions, repair and maintenance expenses, life time of the project and financing options available for renewable energy adoption. In a related study, SSA countries energy frameworks (grid connection, infrastructure) are highly underdeveloped which makes it difficult to develop effective and dependable renewable energy systems (ODI, 2012). For instance, in 2009, SSA generated 74Gwh of energy from wave, wind, solar and tide systems when held in comparison to 51480Gwh in non-OECD nations (IEA, 2011). In addition, AfDB (2010) comments that providing electricity to $66 \%$ of the African people in rural areas requires large and expensive network and grid facilities.

\subsection{High transaction costs}

Transaction costs are expenses incurred through conducting business operations. Renewable energy schemes are generally small when they are compared to traditional energy schemes, which considerably produce high transaction costs (UNEP FI, 2012). For instance, transaction costs incurred by a single coal plant will be significantly reduced when compared to the total costs of thousands solar systems in homes (UN Technical Co-operation, 2011). On that account, private financiers are highly expected to choose the coal plant option. Moreover, renewable energy scheme demands crucial information on past weather elements such as rainfall, wind, humidity, sun's radiation and temperature, which are highly unavailable in SSA countries since they are hardly recorded (UNEP FI,2012). This increases uncertainty of renewable energy performance in SSA, thereby changing into schemes that need extra time, and require special attention and financing, thereby considerably increasing transaction costs when they are compared to conventional energy projects (Beck and Martinot,2004). Furthermore, renewable costs have remained high for Africa since most of the technology is imported (Wamukonya, 2007) and they also face high taxes (Beck and Martinot, 2004). Thus, business operations in Africa that deal with renewables have been estimated to cost 20-30\% more when they are compared with other global developing regions (World Bank Group, 2005).

\subsection{Low Carbon Risk}

There is evidence of Low Carbon Risk in SSA (UNEP FI, 2012). Low Carbon Risk means that investments that have been designed for renewable energy adoption are highly vulnerable to become reversed or modified. The main contributory factors are change in public policy, alteration as regards to timeframe of such projects and low commitment by responsible government (Helm et al., 2003) or even, the loss of investor confidence (Renewable Energy Focus, 2010). Moreover, current investment practices that may seek to decarbonise the energy sector are likely to generate high electricity prices in the short run (The Committee on Climate Change, 2013). Thus, deployment of renewables, energy saving techniques and other green innovation frameworks require critical assessments and the information is currently not available, which also increases operating and investment risk.

\subsection{Negative social impacts}

Cooking habits have been a barrier towards full use of improved fuelwood stoves since the local people are not used to 
modernised cooking practices (Bailis et al., 2009). In addition, local populations can also resist renewable energy projects since it displaces them from their ancestral lands. For instance, Biofuel production requires large tracts of land which minimise local use of land and water resources (ODI, 2012). For this reason, Malawi and Rwanda barely have land (Deininger, 2011). In the same vein, employment of biomass energy resources (dung, wood and crop residues) in developing countries has been estimated at $630 \mathrm{kgs} /$ person (Kitani, 1999) to $1000 \mathrm{kgs} /$ person (Hall, 1992), which also increases deforestation rate. In addition, burning biomass fuels produces more than 200 various chemical pollutants which are released into the atmosphere (Godish, 1991; Alfheim and Ramdahl, 1986), causing millions of people in developing countries to have health problems as a result of polluted smoke (UN-Energy/Africa, 2011).

\section{Solutions towards Supporting Sustainable Energy Provision}

In this section, the paper identifies possible solutions to the problems of supporting sustainable energy in SSA mentioned in the previous section. For this reason, possible solutions have been noted as: employing renewable energy targets; deploying feed-in tariffs; integrating Clean Development Mechanisms (CDMs); phasing out monopoly power utilities; external assistance; tax incentives; increasing independent power producers and expanding Rural Electrification Programmes.

\section{Renewable Energy Targets}

The private sector is mainly interested in short-term financial returns. Therefore, the public sector can incorporate policies and mechanisms which are highly attractive to the private sector and also, at the same time benefiting the economy as a whole. For example, these mechanisms can be brief national targets on renewable energy production. National targets that are vision inspired and formulated at national capacity build dependability and trust to the private sector, especially from the financing perspective. Therefore, "targets are usually set as a percentage of the primary energy and/or electricity generation mix" (REN21, 2006). Renewable energy targets are also instrumental in minimising regulatory risks connected with policy incentives that renewable energy investments will eventually depend upon. Thus, they are important towards improving large scale deployment of renewables, speeds up transition to green energy, which makes them a vital substitute to carbon price (Australian Government, 2013). Moreover they are crucial as a result of long investment cycles associated with renewables and the fact that financing liberalised energy markets heavily rely on trust (Bloomberg, 2013). Currently, only eight SSA nations have incorporated national renewable energy targets (UNEP FI, 2012).

\section{Deploying Feed-In Tariffs}

Feed-in tariffs is a tool by which long-run contracts are sold to renewable energy producers at predetermined fixed costs or it may add a fixed premium on the existing market price. That being so, private investors are capable of obtaining positive financial returns since expenses in renewable energy resources are covered through the prescribed abovemarket price premium incorporated. Furthermore, market risk is considerably minimised since non-exhaustible energy generation incentives are provided at prearranged level and for a pre-set number of years which enhances revenue projections to become more precise (Weron, 2007). Hence, feed-in tariffs have been considered to be very effective and most widely implemented with respect to energy financing (DB Climate Change Advisors, 2011). In Kenya, the instituted feed-in tariff scheme by the responsible government is expected to produce 1300MW of additional energy (Kenyan Ministry of Energy, 2011). In another study, the Kakira Sugar Works Co-generation expansion Project generated 12MW of electricity after joint contributions and participation with the Uganda government. So, it is an example of public-private partnerships that promote feed-in tariffs with respect to renewables (Nakhooda, 2005). The project was expected to generate 19MW; the 7MW could be for the use by the plant and 12MW would be channelled to the national grid. Thus, the Bank of Uganda added US\$8.6 million, whilst a subsidy of US\$3.3 million was received from the Rural Electrification Agency. The Power Purchase Agreement states that Uganda Electricity Transmission Company Limited (UETCL) shall purchase 6MW valued at US4.9 cents/kWh (because of the subsidy) and the remainder will be bought at US6.15 cents/kWh (Nakhooda, 2005). At present, only Uganda, Tanzania and Kenya have widely used feed-in tariffs in SSA (UNEP FI, 2012).

\section{Integrating Clean Development Mechanisms (CDMs)}

Clean Development Mechanism (CDM) as defined in Article 12 of the Kyoto Protocol is "a process of certifying emission 
reductions achieved by projects executed in developing countries" (World Bank, 2008, p.6). Hence, SSA countries must integrate Clean Development Mechanisms (CDMs) that are also important in reducing carbon emissions, thereby generating environments for possible carbon emission reduction revenues. Such policies will enhance private entities to invest in CDMs instead of traditional energy sources. In SSA, no country has, at present, put a price on carbon and only $1 \%$ of SSA nations have CDM projects (UNEP FI, 2012). Necessarily to CDM practitioners, it is crucial to offer Certified Emission Reductions (CERs) or Carbon Credits (CC) on the market so as to sell power in the future. Therefore, instruments such as Carbon Finance are important since they "ascertain the future revenues from the sale of the CERs, typically by setting Emission Reduction Purchase Agreements (ERPAs), which commit both the CDM project developer and a CER buyer (e.g., a carbon fund) to such transactions" (World Bank, 2008, p.6).

Thus, Carbon finance indicates a new method of improving investment in schemes that minimise carbon emissions, by that it means moderating climate change, along with promoting sustainable advancement practices (Kossoy, 2005). For instance, the Bumbuma hydropower scheme in Sierra Leone is a good example of carbon finance for social equity project. The government contributed US\$8.9 million, IDA US\$12.5 million, AfDB US\$3.8 million, OPEC Development facility US $\$ 8.4$ million, the Italian government US\$19.9 million and Netherlands Clean Development (NCD) facility US $\$ 0.3$ million (World Bank, 2005). On that account, the emissions reduction contract was put into action for NCD facility to purchase 880000 of carbon emissions that will be produced by the scheme (WorldBank, 2005). The revenue shall be used to develop affected communities through provision of water, roads, schools and health centres.

\section{Phasing Out Monopoly Power Utilities}

Countries must do away with monopoly structures in the energy sector so that fair competition and access to energy markets is enhanced. Such a step fosters private financiers to increase investment in sustainable energy practices (UNEP FI, 2012). Ideally, privatisation of government controlled power sector utilities into private institutions can also assist to phase out subsidies and enhance maximisation of profits (Beck and Martinot, 2004), as in Zimbabwe, Malawi, Nigeria, Ethiopia, Kenya and Nigeria (UNIDO,2012). Africa's power sector should support unbundling the production and transmission of electricity, along with increasing private entity involvement with energy matters at the generation and distribution capacities (Malgas et al., 2007). Unbundling promotes non-discriminatory access to energy supply and it ensures that no cross-subsidisation involving enterprises which are regulated and not regulated take place. For instance, unbundling practices in the sector have been noted in Kenya, Uganda and Ghana (Eberhard and Gratzwick, 2008). Hence, developing suitable organisational structures is important so as to design well defined roles and responsibilities that each participant is expected to undertake. This will assist private investors to minimise time, reduce transaction expenses, and propel fast financial closure of schemes. An agency that handles renewable energy matters is also important to set up. In addition, decentralising energy planning so that all stakeholders are engaged towards supporting renewable energy investments is of crucial importance.

\section{External Assistance}

External or international assistance from countries and development financial entities can assist to reduce investment risks in sustainable energy deployment by use of guarantees and hedging instruments (UNEP FI, 2012). Given that renewable energy costs have been estimated to be lowering (OECD/IEA, 2010; Hamilton, 2010) and its financial assistance shall appropriately be based upon official development assistance (ODA), or even global environmental finance. For example, Grants "do not require repayment: they are essentially "gift" money with specific requirements or terms for use. Governmental and international organisations offer grants to promote environmental and development policies" (UNIDO/REEEP, 2013, p.19.10). On the other hand, Guarantees "are a contractual promise from a financing or otherwise well capitalised organisation to take responsibility for payment of a debt if the primary liable organisation fails to pay."(UNIDO/REEEP, 2013, p.19.11). Thus, grants are a form of ODA, whilst Guarantees are a form of environmental finance instrument towards expanding support for renewable energy adoption.

\section{Tax Incentives}

Tax incentives take place when citizens make tax declarations by deducting a certain percentage of the investment expense on their renewable energy resources or energy efficiency practices spread over specified number of years from their tax bill (RES, 2009). Thus, they play a major role in the energy sector, thereby generating large impacts on renewable technology adoption schemes (Rader et al., 1998). On that account, profitable tax frameworks towards 
renewable energy incorporation are investment tax credits, property and sales tax deductions or relief, and production tax credits (Wiser and Pickle, 1997). Therefore, it is crucial to incorporate investment and production tax credits to investors linked with renewable energy. They are normally important to account for the expense in purchasing systems (e.g. wind turbine) or the complete costs of installing renewable energy technologies. Since costs are normally high at the early stages, they can be of great importance, in addition to supporting off-grid remote areas. Tax relief measures such as carbon tax exemptions on deployment of renewable energy are also valuable options. For the most part, these tax structures are crucial in order to support different energy supplies, remove tax hindrances that affect renewable energy adoption and to promote fairness in the energy sectors tax policy (Burtraw and Shah, 1995).

\section{Increase Independent Power Producers}

Independent Power Producers (IPPs) include renewable energy developers and other partners who drive cleaner energy production innovations. On that note, IPPs guarantees that electricity supply is promoted, ensure that energy markets are fair in terms of access, integrate effective pricing and regulatory policies, plus, they introduce cost effective best practices in the sector (NPCC,2006). For example, inorder to promote large scale renewable energy adoption in SSA, the Mauritius government, together with independent entrepreneurs jointly participated in energy projects that would generate $30 \%$ electricity for the country from the sugarcane industry (Deepchand, 2001; 2002). Thus, 1.8 million of sugar-cane residues from the industry could be used to generate electricity. The government incorporated the Bagasse Transfer Fund and the Sugar Investment Trust which would enable all stakeholders to share revenue equally (Deepchand, 2001). Thus, cleaner production practices were supported and involvement of independent power producers was also facilitated (Deepchand, 2001: 2002).

\section{Expanding Rural Electrification Programmes}

Rural Electrification Programmes must integrate renewable energy in their policy, planning and management which compels regulated companies to function in such areas (Beck and Martinot, 2004). On that account, private entities are also able to provide renewable energy technologies to their customers through microcredit facilities which support economic development. Moreover, an energy resource information database is vital for the planning and management of renewable energy policies and projects so as to determine their potential in rural areas (Martinot et al., 2002). As such, appropriate information databases will assist project developers to formulate and carry out achievable plans and projects. It will also enhance the adoption of specific energy technologies, along with determining particular service delivery frameworks based on needs. For instance, improvements in renewable technologies have seen solar and wind energy costing half of their mid-1990s values (REN21, 2005), which implies that particular green technologies have become more efficient.

\section{Conclusion}

This paper focused on the problems of sustainable energy in sub-Saharan African countries and their possible solutions. By utilising previous studies, the major problems identified are: continued employment of fossil fuel subsidies; the presence of monopoly structures in the energy sectors; regulatory and macroeconomic risks in sustainable energy schemes; large capital required to fund sustainable schemes; high transaction costs; low carbon risk and negative social factors. The solutions identified are that countries must employ renewable energy targets; deploy feed-in tariffs; integrate Clean Development Mechanisms (CDMs); phase out monopoly power utilities; seek external assistance; introduce tax incentives; increase independent power producers and expand Rural Electrification Programmes. In general, it is quite evident that the advantages of integrating sustainable energy integration simply outweigh its associated disadvantages. That being the case, sub-Saharan African countries must incorporate efficient policies in their governance so that sustainable energy development priorities are attained.

\section{References}

AfDB (African Development Bank), 2008. Clean energy investment framework for Africa. Operations Policies and Compliance Department, AfDB.

AfDB (African Development Bank), 2010. Committee of Ten Policy Brief: Financing of Sustainable Energy Solutions. Committee of Ten Policy Brief. 3, AfDB. 
African Economic Outlook, 2011. Special theme: Africa and its Emerging Partners. http://www.undp.org/content/dam/undp/library /corporate/Reports/UNDP-Africa-2011-Economic-Outlook.pdf Accessed September 2013.

Alfheim, I \& Ramdahl, T, 1986. Mutagenic and Carcinogenic Compounds from Energy Generation. Center for Industriforkning. Oslo, Norway.

Alstorm, 2013. Bujagali-Powering. http://www.alstom.com/Global/Power/Resources/Documents/Brochures/bujagali-uganda-kaplanhydro-plant-advertorial.pdf Accessed March 2013.

AICD (Africa Infrastructure Country Diagnostic), 2008. Under powered: The State of the Power Sector in Sub-Saharan Africa. Washington DC.

AREED-II,2013. The African Rural Energy Enterprise Development -AREED-II. http://www.areed.org/downloads/reports/AREEDII2013_FACT_SHEET.pdf Accessed March 2013

Australian Government, 2013. Renewable Energy Target. http://www.climatechange.gov.au/reducing-carbon/renewable-energy/ renewable-energy-target Accessed September 2013.

Beck, F \& Martinot, E, 2004. Renewable energy policies and barriers. Encyclopedia of energy, 5,365-383.

Bloomberg, 2011. Wind Turbine Prices Below 1 Million Euros a Megawatt. http://www.bloomberg.com/news/2011-02-07/wind-turbineprices-fall-below-1-million-euros-per-megawatt-bnef-says.html Accessed October 2013.

Bloomberg, E, 2013. Industry Leaders Urge EU to Support 2030 Renewable Energy Target. http://www.renewableenergyworld.com /rea/news/article/2013/09/industry-leaders-urge-eu-to-support-2030-renewable-energy-target Accessed October 2013.

Briceño-Garmendia, C, Smits, K \& Foster, V, 2008. Financing Public Infrastructure in Sub-Saharan Africa: Patterns, Issues, and Options, AICD Background Paper 15. Africa Infrastructure Sector Diagnostic, Washington DC: World Bank.

Burtraw, D \& Shaw, P, 1995. Fiscal Effects of Electricity Generation: A Full Fuel Cycle Analysis, Discussion Paper 95-16.Resources for the Future, Washington DC.

CEPEX-Rwanda, 2010. Multilaterals Worldbank Portfolio. http://www.cepex.gov.rw/system/files/annex1.pdf Accessed August 2013.

Committee on Climate Change, 2013. Managing competitiveness risks of low-carbon policies. The Digital Parent Company, London.

Dasappa, S, 2011. Potential of biomass energy for electricity generation in sub-Saharan Africa. Energy for Sustainable Development, 15(3), 203-213.

DB Climate Change Advisors, 2011.De-risking Clean Energy Business Models in a developing country context. http://www.dbcca.com/dbcca/EN/_media/GET_FiT_Plus.pdf Accessed August 2013.

Deepchand, K, 2001. Bagasse-Based Cogeneration in Mauritius - A model for Eastern and Southern Africa, Occasional Paper No. 2. AFREPREN, Nairobi.

Deepchand, K,2002. Promoting equity in the large-scale renewable energy developments: The case of Mauritius. Energy Policy $30,11-$ 12.

DEG (German Investment Corporation), 2010. DEG Case Study: OLKARIA - Geothermal Power Plant - Kenya Internal document.

Deichmann, U, Meisner, C, Murray, S \& Wheeler, D, 2010. The Economics of Renewable Energy Expansion in Rural sub-Saharan Africa. World Bank Policy Research Working Paper 5193, Washington DC.

Deininger, K, Byerlee, D, Lindsay, J, Norton, A, Selod, H \& Stickler, M, 2011. Rising Global Interest in Farmland: Can it Yield Sustainable and Equitable Benefits? World Bank, Washington DC.

Eberhard, A \& Gratzwick, $\quad$ KN, 2008. IPPs in Sub-Saharan Africa: determinants of success. http://siteresources.worldbank.org IAFRICAEXT/Resources/258643-1271798012256/Africa_IPP.pdf Accessed September 2013.

ESKOM (Electricity Supply Commission), 2013. Renewable Energy: Sere wind farm. http://www.eskom.co.za/content/Sere\%20Wind.pdf Accessed September 2013

Fraunhofer, 2012. Levelised cost of electricity renewable energies. Fraunhofer Institute for Solar Energy Systems, Germany.

Foster, V \& Steinbuks, J, 2008. Paying the Price for Unreliable Power Supplies: In-House Generation of Electricity by Firms in Africa, Policy Research Working Paper 4913. World Bank, Washington DC.

GEF (Global Environment Facility), 2009. Global Environment Facility-Uganda 2009, http://www.thegef.org/gef/sites/thegef.org /files/repository/Uganda_02-26-2009-ID3892_Energy_Rural_Transformation_II.pdf Accessed August 2013.

Godish, T, 1991. Air Quality. Lewis Publishers, Chelsea (MI).

Hall, DO, 1992. Biomass. World Bank, Washington DC.

Hamilton, K, 2010. Scaling up Renewable Energy in Developing Countries: finance and investment perspectives. Energy, Environment \& Resource Governance Programme Paper 02/10, Chatham House, London.

Helm, D, Hepburn, C \& Mash, R, 2003. Credible Carbon Policy. Oxford Review of Economic Policy, 19(3), 438-450.

Holm, A, Blodgett, L, Jennejohn, D \& Gawell, K, 2010. Geothermal Energy: International Market Update. Geothermal Energy Association-GEA.

ICSU (The International Council for Science), 2007. Sustainable Energy in sub-Saharan Africa. ICSU Regional Office for Africa, Republic of South Africa.

IEA (International Energy Agency), 2002. World Energy Outlook. International Energy Agency, Paris.

IEA (International Energy Agency), 2010. Analysis of the Scope of Energy Subsidies and Suggestions for the G-20 Initiative. http://www.oecd.org/env/45575666.pdf Accessed September 2013.

IEA (International Energy Agency), 2011. Clean Energy Progress Report. OECD/IEA, Paris.

IEA (International Energy Agency), 2011. Energy Statistics for non-OECD Countries. IEA, Paris.

IFC (International Finance Corporation), 2012. Affordable and Reliable Solar Systems in Northern Tanzania. LADM 4509_Affordable, 
reliable solar lighting in Tanzania.pdf Accessed October 2013.

IPCC (Intergovernmental Panel on Climate Change), 2011. Special Report on Renewable Energy Sources and Climate Change Mitigation. UN Climate Change Conference June 2011, Bonn, Germany.

Jaramillo, L,2010. Determinants of Investment Grade Status in Emerging Markets, IMF Working paper. http://www.imf.org/external/pubs/ft/wp/2010/wp10117.pdf Accessed March 2013.

Karekezi, S, Teferra, M \& Mapako, M, (Eds.). 2002. SPECIAL ISSUE - Africa: Improving modern energy services for the poor. Energy Policy, 30, (11-12). Elsevier Science, Oxford.

Kellet, J, 1990. The environmental impacts of wind energy developments. Town Planning Review, 91,139-154.

Kenyan Ministry of Energy, 2011. Scaling up renewable energy program: Investment plan for Kenya, draft May 2011. http://www.renewableenergy.go.ke/downloads/policy-docs/Updated_SREP_Draft_Investment_Plan_May_2011.pdf Accessed September 2013

Kitani, O, 1999. Biomass resources. In Kitani, O, Jungbluth, T, Peart, RM \& Ramdami A, (Eds). Energy and Biomass Engineering, pp. 6 11. St. Joseph (MI): American Society of Agricultural Engineers.

Knight, M, 1998. Developing countries and the globalisation of financial markets. World Development, 26, 1185-2000.

KPMG, 2011. Sub-Saharan Africa Power Outlook. KPMG Services (Proprietary) Limited, South Africa.

Kossoy, A, 2005. The Role of Carbon Finance in Project Development. In: Semida, S (Ed): Bioenergy. Realizing the potential, pp.179187. Elsevier.

Martinot, E, Chaurey, A, Lew, D, Moreira, JR, \& Wamukonya, N, 2002. Renewable energy markets in developing countries. Annual Review of Energy and the Environment, 27,309-348.

Nakhooda, F, 2005. Kakira Sugar Works Cogeneration Project. http://www.partners4africa.org/docs/S2-8-Nkhooda-PfA-Tanzania0506.pdf Accessed September 2013

Nkwetta, DN, Smyth, M, Van Thong, V, Driesen, J \& Belmans, R, 2010. Electricity supply, irregularities, and the prospect for solar energy and energy sustainability in Sub-Saharan Africa. Journal of Renewable and Sustainable Energy 2(2), 023102.

NPCC (Northeast Power Coordinating Council), 2006. The Role of the Independent Power Producers. http://www.nippc.org/upload/LSI_Speech_012006.pdf Accessed 27 August 2013.

ODI (Overseas Development Institute), 2012. Sub-Saharan Africa in global trends of investment in renewable energy. Drivers and the challenge of the water-energy-land nexus. ODI and Deutsches Institut für Entwicklungspolitik (DIE) publication.

OECD (Organization for Economic Co-operation and Development), 2010. Interim Report of the Green Growth Strategy: Implementing our Commitment for a Sustainable Future. OECD, Paris.

OECD/IEA (Organization for Economic Co-operation and Development/ International Energy Agency), 2010. World Energy Outlook. IEA, Paris.

OPEC (Organization of the Petroleum Exporting Countries), 2010. World Oil Outlook 2010. Vienna: OPEC.

Pegels, A, 2009. Prospects for renewable energy in South Africa mobilizing the private sector, Discussion Paper/ 23/2009. Deutsches Institut für Entwicklungspolitik (DIE).

PIDG (Private Infrastructure Development Group), 2013). Olkaria Geothermal Power Plant, http://www.pidg.org/impact/casestudies/olkaria-geothermal-power-plant Accessed March 2013

pv magazine, 2010. South Africa: Grid parity within sight, but Refit needs to be implemented soon.http://www.pvmagazine.com/news/details/beitrag/south-africa--grid-parity-within-sight--but-refit-needs-to-be-implementedsoon_100000754/\#axzz2h1PUbyGq Accessed August 2013.

Rader, N, Wiser, R, \& Schwartz, S, 1998. Strategies for Promoting Wind Energy: A Review and Analysis of State Policy Options, January 1998, New Draft Executive Summary for Review by the NWCC. NWCC.

Ram, B, 2006. Renewable Energy Development in Africa- Challenges, Opportunities, Way Forward. South Africa Regional Office, African Development Bank.

Rambo, CM, 2013. Renewable energy project financing risks in developing countries: Options for Kenya towards the realization of vision 2030. International Journal of Business and Finance Management Research,1,1-10.

REEEP/UNIDO(Renewable Energy and Energy Efficiency Partnership/ United Nations Industrial Development Organization), 2011. Training manual on Sustainable Energy Regulation and Policymaking for Africa. REEEP/UNIDO publication.

REN21 (Renewable Energy Policy Network for the 21st Century), 2005. Renewable Energy 2005 Global Status Report. REN21, Washington DC.

REN21 (Renewable Energy Policy Network for the 21st Century),2006. Changing Climates: The Role of Renewable Energy in a CarbonConstrained World. UNEP/REN21 publication.

REN21 (Renewable Energy Policy Network for the 21st Century), 2011. Renewables 2011 Global Status Report. REN21 Secretariat, Paris.

Renewable Energy Focus, 2010. Czech Tax on Solar PV Revenues. http://www.renewableenergyfocus.com/view/14645/czech-tax-onsolar-pv-revenues/ Accessed August 2013.

The Ministry of Energy-Mozambique, 2009. MZ-Energy Development and Access Project (APL-2). http://wwwwds.worldbank.org/external/default/WDSContentServer/WDSP/IB/2009/10/13/000101930_20091015134132/Rendered/PDF/Proj ect0Inform1sal0Stage0October010.pdf Accessed September 2013.

Thiam, DR, 2010. Renewable decentralised in developing countries: Appraisal from micro- grids project in Senegal. Renewable Energy, 35(8), 1615-1623. 
Timilsina, GR, de Gouvello, C, Thioye, M \& Dayo, FB,2010. Clean Development Mechanism Potential and Challenges in sub-Saharan Africa. Mitigation and Adaptation Strategies for Global Change, 15, 93-111.

TMSA (TradeMark Southern Africa), 2010. Kariba extension project to get $\$ 430$ million. http://www.trademarksa.org/news/karibaextension-project-get-430-million Accessed August 2013.

UN-Energy/Africa, 2011. Energy for Sustainable Development: Policy Options for Africa. Publication to CSD15, UN-Energy/Africa.

UNEP (United Nations Environment Programme), 2008. Global Trends in Sustainable Energy Investment Report 2008: Analysis of Trends and Issues in the Financing of Renewable Energy and Energy Efficiency. UNEP and New Energy Finance Ltd, London.

UNEP (United Nations Environment Programme), 2010. Private Financing of Renewable Energy- A guide for policymakers. Renewable Energy Finance Project, Chatham House.

UNEP (United Nations Environment Programme),2013. The en.lighten initiative: Lighting the Future We Want. UNEP publication.

UNEP FI (United Nations Environment Programme Finance Initiative), 2012. Financing renewable energy in developing countries: Drivers and barriers for private finance in sub-Saharan Africa. International Environment House, Switzerland.

UNECA/UNEP (United Nations Economic Commission for Africa/, United Nations Environment Programme), 2007. Making Africa's Power Sector Sustainable: An Analysis of Power Sector Reforms in Africa. Addis Ababa, UN-Energy/Africa.

UNIDO (United Nations Industrial Development Organization), 2012. The reform of the power sector in Africa, Module 4.http://www.unido.org/fileadmin/media/documents/pdf/EEU Training Package/Module4.pdf Accessed September 2013.

UNIDO/REEEP (United Nations Industrial Development Organization/Renewable Energy and Energy Efficiency Partnership), 2013. Financing options for renewable energy and energy efficiency. http://www.unido.org/fileadmin/media/ documents/pdf/EEU_Training_Package/Module19.pdf Accessed September 2013

UN Technical Cooperation, 2011. Capacity-building for Rapid Commercialisation of Renewable Energy. http://esa.un.org/techcoop/ flagship.asp ?Code=CPR97G31 Accessed September 2013

US EIA (United States International Energy Agency), 2011. International Energy Statistics. .http://www.eia.doe.gov/cfapps/ipdbproject liedindex3.cfm?tid=2\&pid=2\&aid=12\&cid=r6,\&syid=1998\&eyid=2008\&unit=BKWH Accessed September 2013.

Wamukonya, N, 2007. Solar home system electrification as a viable technology option for Africa's development. Energy Policy, 35(1), 614.

WEC (World Energy Council), 2002. Appropriate Energy Mix for Africa, paper for Workshop of the Nigerian Institute of Engineers, Lagos, 22 March 2001.WEC publication, Nigeria.

WEC (World Energy Council), 2005. Regional Energy Integration in Africa. A report of the World Energy Council, London.

Weron, R, 2007. Modeling and Forecasting Electricity Loads and Prices: A Statistical Approach. Chichester: .John Wiley.

Wise, R \& Pickle, S,1997. Financing Investments in Renewable Energy: The Role of Policy Design and Restructuring. Environmental Energy Technologies Division, University of California, U.S.

World Bank, 2005. Meeting the Challenge of Africa's Development, a World Bank Group Action Plan. World Bank,Washington DC.

World Bank, 2005. Sierra Leone - Completion of the Bumbuna Hydroelectric Project. Washington DC. - The Worldbank. http://documents.worldbank.org/curated/en/2005/05/5828409/sierra-leone-completion-bumbuna-hydroelectric-project Accessed September 2013

World Bank,2008. Low-carbon Energy Projects for Development in sub-Saharan Africa: Unveiling the Potential, Addressing the Barriers. Office of the Publisher, Washington DC, USA.

World Energy Council, 2010. 2010 Survey of Energy Resources. WEC, London. 
